\title{
Pengaruh Teknik Pembelajaran dan Gaya Belajar Terhadap Hasil Belajar IPS Siswa Kelas IV SDN 014680 Buntu Pane Kisaran
}

\section{The Effect of Learning Techniques and Learning Styles toward the Social Studies Learning Outcomes of Class IV Students SDN 014680 Buntu Pane Range}

\author{
Widya Firdausi Lasty \\ Fakultas Tarbiyah, Institut Agama Islam Daar Al Uluum,Indonesia
}

Diterima :11 Agustus 2020; Disetujui : 24 Agustus 2020; Dipublish : 29 Agustus 2020

*Corresponding author: E-mail: widyalasty458@gmail.com

\begin{abstract}
Abstrak
Penelitian ini dilaksanakan di SD Negeri No.014680 Buntu Pane Kisaran pada semester genap tahun ajaran 2013/2014. Populasinya adalah seluruh siswa kelas IV sebanyak 50 siswa. Sampelnya adalah semua siswa yang mengambil mata pelajaran IPS sebanyak 25 siswa pada kelas IVA dan sebanyak 25 siswa pada kelas IV B. Instrumen yang digunakan untuk mengumpul data adalah tes hasil belajar IPS dan angket gaya belajar. Metode penelitian menggunakan metode quasi eksperimen dengan desain penelitian faktorial 2x2. Teknik analisis data menggunakan ANAVA pada taraf signifikan $\alpha=0,05$. Hasil penelitian menunjukkan (1) Hasil belajar IPS siswa yang diajarkan dengan teknik kunjungan lapangan lebih tinggi dibadingkan dengan teknik penyajian kasus $\left(F_{\text {hitung }}=19,86>F_{\text {tabel }}=4,05\right)$, (2) Hasil belajar IPS Siswa yang memiliki gaya belajar visual lebih tinggi dibandingkan dengan gaya belajar auditori $\left(F_{\text {hitung }}=8,65>F_{\text {tabel }}=4,05\right)$. (3) Terdapat interaksi teknik pembelajaran dan gaya belajar siswa dalam mempengaruhi hasil belajar IPS siswa auditori $\left(F_{\text {hitung }}=6,52>F_{\text {tabel }}=4,05\right)$. Data ini menunjukkan, teknik pembelajaran dan gaya belajar berpengaruh terhadap hasil belajar IPS siswa.
\end{abstract}

Kata Kunci : Teknik Pembelajaran; Gaya Belajar; Hasil Belajar IPS

\begin{abstract}
This research was conducted at SD Negeri No.014680 Buntu Pane Kisaran in the even semester of the 2013/2014 school year. The population is all fourth grade students as many as 50 students. The sample is all students who take social studies as many as 25 students in class IVA and as many as 25 students in class IV B. The instruments used to collect data are social studies learning outcomes test and learning style questionnaire. The research method used a quasi-experimental method with a $2 \times 2$ factorial research design. The data analysis technique used ANOVA at the significant level $\alpha=0.05$. The results showed (1) the social studies learning outcomes of students who were taught by field visit techniques were higher than the case presentation techniques (Fcount $=19.86>$ Ftable $=4.05$ ), (2) Social studies learning outcomes of students who had more visual learning styles. higher than the auditory learning style (Fcount $=8.65>$ Ftable $=4.05$ ). (3) There is an interaction of learning techniques and student learning styles in influencing auditory student social studies learning outcomes (Fcount $=6.52>$ Ftable $=4.05$ ). This data shows, learning techniques and learning styles have an effect on student social studies learning outcomes.

Keywords : Learning Techniques; Learning Styles; Social Studies Learning Outcomes
\end{abstract}

Rekomendasi mensitasi :

Lasty, W.F. 2020. Pengaruh Teknik Pembelajaran dan Gaya Belajar Terhadap Hasil Belajar IPS Siswa Kelas IV SDN 014680 Buntu Pane Kisaran. Jurnal Penelitian Pendidikan, Psikologi dan Kesehatan (J-P3K), 1 (2): 143-156. 


\section{PENDAHULUAN}

Salah satu faktor ekstern yang penting dalam memperoleh hasil belajar siswa yaitu, kemampuan guru (profesionalisme guru) dalam mengelola pembelajaran. Guru sangat berperan penting karena subjek yang diharapkan mampu melakukan pembaharuan dalam pembelajaran ini adalah seorang guru. Dalam hal ini salah satu tugas guru yaitu harus bisa menciptakan situasi kelas yang menyenangkan bukan menjenuhkan. Sehingga membuat siswa jadi lebih mudah memahami dan mengerti apa yang disampaikan oleh gurunya. Salah satu aspek tersebut yaitu dengan menerapkan teknik pembelajaran dan mengetahui gaya belajar siswa.

Teknik pembelajaran didefinisikan sebagai daya upaya, atau usaha-usaha yang ditempuh oleh seseorang guru dalam rangka untuk mencapai suatu tujuan pengajaran. Dengan menerapkan teknik pembelajaran diharapkan dapat memberikan kemudahan bagi siswa untuk mempelajari materi pelajaran, sehingga hasil belajar menjadi lebih baik. Khususnya pada mata pelajaran IPS yang umumnya materi pelajarannya di sajikan dalam bentuk hafalan (verbalistik).

Dengan penyajian seperti itu tentu dapat menimbulkan kebosanan pada siswa, sehingga minat belajar mereka terhadap pelajaran IPS menjadi rendah yang mengakibatkan hasil belajar IPS siswa juga menjadi rendah. Sedangkan Gaya belajar adalah kombinasi dari bagaimana ia menyerap dan kemudian mengatur serta mengolah informasi. Gaya belajar merupakan sesuatu yang sangat penting dan sangat menentukan bagi siapapun dalam melaksanakan tugas belajarnya baik di rumah, di masyarakat, terutama di sekolah

Berdasarkan uraian-uraian di atas, maka dapat dilakukan penelitian mengenai Pengaruh Teknik Pembelajaran dan Gaya Belajar Terhadap Hasil Belajar IPS Siswa Kelas IV SDN 014680 Buntu Pane Kisaran. Tujuan penelitian ini adalah untuk melihat pengeruh teknik pembelajaran dan gaya belajar terhadap hasil belajar IPS siswa kelas IV SDN 014680 Buntu Pane Kisaran.

\section{METODE PENELITIAN}

Penelitian ini dilakukan di Kelas IV SDN 014680 Buntu Pane Kisaran terhitug mulai bulan mei sampai juni Tahun Pembelajaran 2013/2014. Populasi dalam penelitian ini adalah seluruh kelas IV A dan IV B yang masing-masing kelas berjumlah 25 orang, sehingga populasi penelitian berjumlah 50 orang. Sampel yang digunakan 2 kelas, yaitu 1 kelas menggunakan Teknik kunjungan lapangan dan 1 kelas dengan menggunakan Teknik penyajian secara kasus.

Penelitian ini merupakan penetian eksperimen dengan disain penelitian yang digunakan adalah desain faktorial 2 x 2 . Sebagai variable bebas pertama yaitu teknik pembelajaran, dengan dua taraf yaitu teknik kunjungan lapangan dan Teknik penyajian secara kasus. Variable moderator yaitu gaya belajar yaitu gaya belajar visual dan gaya belajar auditori. Sedangkan variable terikatnya adalah hasil belajar IPS. Adapun desain penelitian ini dapat dilihat pada Tabel 1. 
Tabel 1. Desain Penelitian Faktorial $2 \times 2$ Kunjungan Teknik Lapangan Penyajian $\left(\mathrm{A}_{1}\right)$ Kasus $\left(\mathrm{A}_{2}\right)$

\begin{tabular}{ccc} 
& & $\left(\mathrm{A}_{2}\right)$ \\
\hline Visual & $\mathrm{A}_{1} \mathrm{~B}_{1}$ & $\mathrm{~A}_{2} \mathrm{~B}_{1}$ \\
$\left(\mathrm{~B}_{1}\right)$ & & \\
\hline Gaya & Teknik Pembelajaran $(\mathrm{A})$ \\
Belajar & &
\end{tabular}
(B)

Auditori $\quad \mathrm{A}_{1} \mathrm{~B}_{2} \quad \mathrm{~A}_{2} \mathrm{~B}_{2}$ $\left(\mathrm{B}_{2}\right)$

Untuk keperluan pengujian hipotesis penelitian, maka dalam hal ini perlu dilakukan teknik pengumpulan data. Teknik pengumpulan data yang dilakukan dengan bentuk tes pilihan berganda dan angket. Sebelum instrument tes digunakan dalam penelitian, sebelumnya dilakukan uji coba terhadap instrument tes tersebut. Tujuannya adalah untuk mengukur apakah instrument tes tersebut mampu mengukur apa yang seharusnya di ukur (validitas, serta keterandalannya (reliabilitas).

Selain itu juga melihat tingkat kesukaran, daya beda dan efektifitas distaktor masing-masing item tes yang diujikan. Dalam penelitian ini uji coba dilakukan di sekolah yang sama di kelas $\mathrm{V}$ SD. Untuk analisis data yang diperoleh dari penelitian ini digunakan perangkat tes parametrik karena asumsi yang melandasi penggunaanya terpenuhi sehingga perangkat tes tersebut sangat kuat untuk menguji hipotesis nol. Hipotesis alternatif adalah hipotesis dugaan jawaban yang dibuat peneliti bagi problematika yang diajukan dalam penelitian. Dugaan jawaban tersebut merupakan kebenaran yang sifatnya sementara, yang akan diuji kebenarannya dengan data yang dikumpulkan melalui penelitian.
Untuk analisis data yang diperoleh dari penelitian ini digunakan perangkat tes parametrik karena asumsi yang melandasi penggunaanya terpenuhi sehingga perangkat tes tersebut sangat kuat untuk menguji hipotesis nol. Hipotesis alternatif adalah hipotesis dugaan jawaban yang dibuat peneliti bagi problematika yang diajukan dalam penelitian. Dugaan jawaban tersebut merupakan kebenaran yang sifatnya sementara, yang akan diuji kebenarannya dengan data yang dikumpulkan melalui penelitian. Sebelum dilakukan uji hipotesis penelitian, data tes kemampuan menulis berdasarkan kelompok perlakuan harus memenuhi persyaratan yaitu dengan uji validitas, homogenitas dan uji statistik.

\section{HASIL DAN PEMBAHASAN}

A.Deskripsi data

Berdasarkan rancangan analisis, maka data yang disajikan adalah (1) hasil belajar Ilmu Pengetahuan Sosial yang diajar dengan teknik kunjungan lapangan, (2) hasil belajar Ilmu Pengetahuan Sosial yang dengan teknik penyajian kasus (3) hasil belajar Ilmu Pengetahuan Sosial yang memiliki gaya belajar visual (4) hasil belajar Ilmu Pengetahuan Sosial yang memiliki gaya belajar auditori (5) hasil belajar Ilmu Pengetahuan Sosial siswa yang diajar dengan teknik kunjungan lapangan dan memiliki gaya belajar visual (6) hasil belajar Ilmu Pengetahuan Sosial siswa yang diajar dengan teknik kunjungan lapangan dan memiliki gaya belajar auditori (7) hasil belajar Ilmu Pengetahuan Sosial yang diajar dengan teknik penyajian kasus dan memiliki gaya belajar visual (8) hasil belajar Ilmu 
Pengetahuan Sosial yang diajar dengan teknik penyajian kasus dan memiliki gaya belajar auditori.

1. Hasil Belajar Ilmu Pengetahuan Sosial yang diajar dengan teknik kunjungan lapangan

Dari data yang diperoleh dan hasil perhitungan statistik diketahui bahwa hasil belajar Ilmu Pengetahuan Sosial yang diajar dengan teknik kunjungan lapangan skor terendah adalah 14, skor tertinggi 22, rata-rata $=18,08$, median $=18,2$ modus $=$ 17,83, simpangan baku $=2,06$. Distribusi frekuensi skor hasil belajar Ilmu Pengetahuan Sosial yang diajar dengan teknik kunjungan lapangan disajikan dalam tabel sebagai berikut.

Tabel 2. Distribusi Frekuensi Hasil Belajar Ilmu Pengetahuan Sosial yang diajar dengan teknik kunjungan lapangan

\begin{tabular}{|c|c|c|c|c|}
\hline No & $\begin{array}{l}\text { Int } \\
\text { Kel }\end{array}$ & & Frekuensi & $\begin{array}{l}\text { Persentase } \\
(\%)\end{array}$ \\
\hline 1 & 14 & - & 153 & 12 \\
\hline 2 & 16 & - & 177 & 28 \\
\hline 3 & 18 & - & 199 & 36 \\
\hline 4 & 20 & - & 215 & 20 \\
\hline 5 & 22 & - & 231 & 4 \\
\hline 6 & 24 & - & 250 & 0 \\
\hline \multicolumn{3}{|c|}{ Jumlah } & 25 & 100 \\
\hline
\end{tabular}

Dari Tabel 2 diketahui bahwa hasil belajar Ilmu Pengetahuan Sosial yang diajar dengan teknik kunjungan lapangan terdapat $48 \%$ di atas rata-rata dan 52\%di bawah rata-rata. Distribusi frekuensi skor hasil belajar Ilmu Pengetahuan Sosial yang diajar dengan teknik kunjungan lapangan secara visual diperlihatkan dalam bentuk gambar histogram sebagai berikut.

\section{Frekuensi}

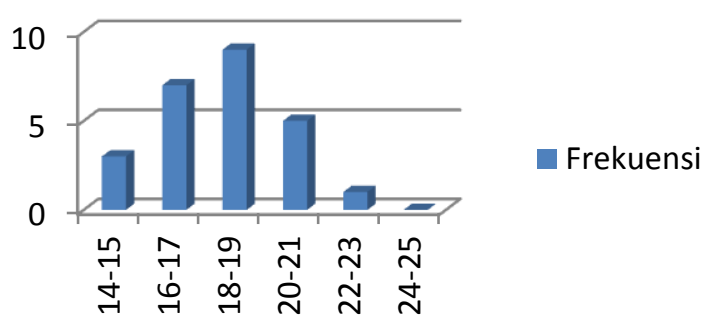

Gambar 1. Histogram Hasil Belajar Ilmu Pengetahuan Sosial yang diajar dengan teknik kunjungan lapangan

2. Hasil Belajar Ilmu Pengetahuan Sosial yang diajar dengan teknik penyajian kasus

Dari data yang diperoleh dan hasil perhitungan statistik diketahui bahwa hasil belajar Ilmu Pengetahuan Sosial yang diajar dengan teknik penyajian kasus skor terendah 14 skor tertinggi 19, rata-rata = 16,88 , median $=16,17$ modus $=16,14$, simpangan baku $=1,53$. Distribusi frekuensi skor hasil belajar Ilmu Pengetahuan Sosial yang diajar dengan teknik penyajian kasus disajikan dalam tabel sebagai berikut.

\begin{tabular}{rccc}
\hline No & $\begin{array}{c}\text { Interval } \\
\text { Kelas }\end{array}$ & Frekuensi & Persentase (\%) \\
\hline 1 & $14-15$ & 5 & 8 \\
2 & $16-17$ & 12 & 48 \\
3 & $18-19$ & 8 & 32 \\
4 & $20-21$ & 0 & 0 \\
5 & $22-23$ & 0 & 0 \\
6 & $24-25$ & 0 & 0 \\
& Jumlah & 25 & 100 \\
\hline
\end{tabular}

Tabel 3 : Distribusi Frekuensi Hasil Belajar Ilmu Pengetahuan Sosial yang diajar dengan teknik penyajian kasus

Dari tabel 3 diketahui bahwa hasil belajar Ilmu Pengetahuan Sosial yang diajar dengan teknik penyajian kasus terdapat 32\% di atas rata-rata dan $68 \%$ di 
bawah rata-rata. Distribusi frekuensi skor hasil belajar Ilmu Pengetahuan Sosial yang diajar dengan teknik penyajian kasus secara visual diperlihatkan dalam bentuk histogram sebagai berikut.

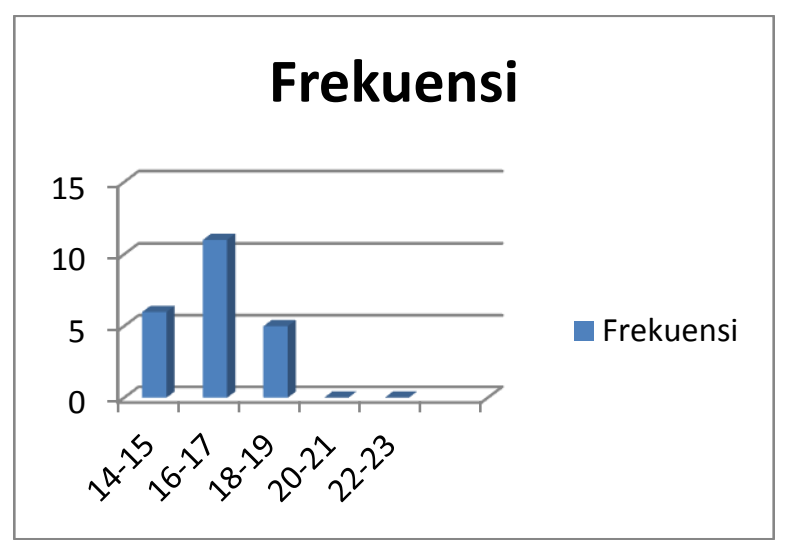

Gambar 2. Histogram Hasil Belajar Ilmu Pengetahuan Sosial yang diajar dengan teknik penyajian kasus

3. Hasil Belajar Ilmu Pengetahuan Sosial yang memiliki gaya belajar visual

Dari data yang diperoleh dan hasil perhitungan statistik diketahui bahwa hasil belajar Ilmu Pengetahuan Sosial yang memiliki gaya belajar visual, skor terendah 15, skor tertinggi 22, rata-rata $=$ 18,29 , median $=18,2$ dan median $=17,5$ dan 18,86, modus $=18,61$, simpangan baku $=1,76$. Berdasarkan data tersebut disusun distribusi frekuensi skor hasil belajar Ilmu Pengetahuan Sosial siswa yang memiliki gaya belajar visual seperti yang dikemukakan pada tabel berikut.
Tabel 4. Distribusi Frekuensi Skor Hasil Belajar Ilmu Pengetahuan Sosial Yang Memiliki Gaya Belajar Visual

\begin{tabular}{cccc}
\hline No & $\begin{array}{c}\text { Interval } \\
\text { Kelas }\end{array}$ & Frekuensi & $\begin{array}{c}\text { Persentase } \\
(\%)\end{array}$ \\
\hline 1 & $15-16$ & 4 & 14 \\
2 & $17-18$ & 10 & 36 \\
3 & $19-20$ & 11 & 39 \\
4 & $21-22$ & 3 & 11 \\
5 & $23-24$ & 0 & 0 \\
\multicolumn{2}{c}{ Jumlah } & 28 & 100 \\
\hline
\end{tabular}

Dari Tabel 4 diketahui bahwa hasil belajar Ilmu Pengetahuan Sosial yang memiliki gaya belajar visual terdapat $50 \%$ di atas rata-rata dan $50 \%$ di bawah ratarata. Distribusi frekuensi skor hasil belajar Ilmu Pengetahuan Sosial siswa yang memiliki gaya belajar visual secara visual diperlihatkan dalam bentuk gambar histogram pada gambar berikut.

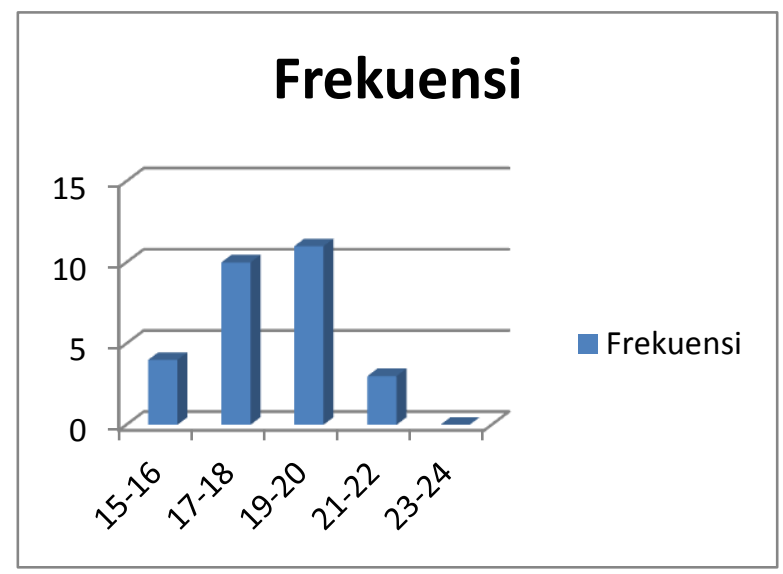

Gambar 3. Histogram Hasil Belajar Ilmu Pengetahuan Sosial Siswa yang Memiliki Gaya Belajar Visual

4. Hasil Belajar Ilmu Pengetahuan Sosial Yang Memiliki Gaya Belajar Auditori

Dari data yang diperoleh dan hasil perhitungan statistik diketahui bahwa hasil belajar Ilmu Pengetahuan Sosial yang memiliki gaya belajar auditori skor terendah 14 , skor tertinggi 19 , rata-rata $=16,45$, median $=15,95$, modus $=15,95$, 
simpangan baku =1,44. (Perhitungan selengkapnya dapat dilihat pada lampiran 9). Berdasarkan data tersebut disusun distribusi frekuensi skor hasil belajar Ilmu Pengetahuan Sosial yang memiliki gaya belajar auditori seperti yang dikemukakan pada tabel berikut.

Tabel 5 Distribusi Frekuensi Skor Hasil Belajar Ilmu Pengetahuan Sosial yang Memiliki Gaya

\begin{tabular}{cccc}
\hline No & $\begin{array}{c}\text { Interval } \\
\text { Kelas }\end{array}$ & Frekuensi & $\begin{array}{c}\text { Persentase } \\
(\%)\end{array}$ \\
\hline 1 & $14-15$ & 6 & 27 \\
2 & $16-17$ & 11 & 50 \\
3 & $18-19$ & 5 & 23 \\
4 & $20-21$ & 0 & 0 \\
5 & $22-23$ & 0 & 0 \\
\multicolumn{2}{l}{ Belajar Auditori } & 22 & 100 \\
\hline
\end{tabular}

Dari tabel 5 diketahui bahwa hasil belajar Ilmu Pengetahuan Sosial yang memiliki gaya belajar auditori, terdapat $50 \%$ di atas rata-rata dan 50\%di bawah ratarata. Distribusi frekuensi skor hasil belajar Ilmu Pengetahuan Sosial yang memiliki gaya belajar auditori secara visual diperlihatkan dalam bentuk gambar histogram pada gambar berikut.

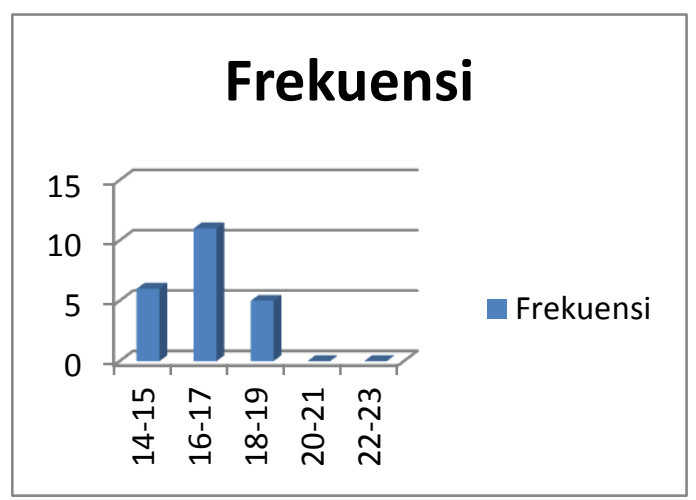

Gambar 4. Histogram Skor Hasil Belajar Ilmu Pengetahuan Sosial yang Memiliki Gaya Belajar Auditori
5. Hasil Belajar Ilmu Pengetahuan Sosial Siswa Yang Diajar Dengan Teknik Kunjungan Lapangan Dan Memiliki Gaya Belajar Visual

Dari data yang diperoleh dan hasil perhitungan statistik diketahui bahwa hasil belajar Ilmu Pengetahuan Sosial siswa yang diajar dengan teknik kunjungan lapangan dan memiliki gaya belajar visual, skor terendah 17 , skor tertinggi 22 , ratarata $=19,27$ median $=18,94$ dan modus $=$ 18,94 dan simpangan baku $=1,44$. Berdasarkan data tersebut disusun distribusi frekuensi skor hasil belajar Ilmu Pengetahuan Sosial siswa yang diajar dengan teknik kunjungan lapangan dan memiliki gaya belajar visual seperti yang dikemukakan pada tabel berikut.

Tabel 6 Hasil Belajar Ilmu Pengetahuan Sosial Siswa Yang Diajar Dengan Teknik Kunjungan Lapangan Dan Memiliki Gaya Belajar Visual

Dari Tabel 6 diketahui bahwa hasil

\begin{tabular}{cccc}
\hline No & Interval Kelas & Frekuensi & $\begin{array}{c}\text { Persentase } \\
(\%)\end{array}$ \\
\hline 1 & $17-18$ & 4 & 27 \\
2 & $19-20$ & 8 & 53 \\
3 & $21-22$ & 3 & 20 \\
4 & $23-24$ & 0 & 0 \\
5 & $25-26$ & 0 & 0 \\
& Jumlah & 15 & 100 \\
\hline
\end{tabular}

belajar Ilmu Pengetahuan Sosial siswa yang diajar dengan teknik kunjungan lapangan dan memiliki gaya belajar visual terdapat $60 \%$ di atas rata-rata dan $40 \%$ di bawah rata-rata. Distribusi frekuensi skor hasil belajar Ilmu Pengetahuan Sosial siswa yang diajar dengan teknik kunjungan lapangan dan memiliki gaya belajar visual secara visual diperlihatkan dalam bentuk gambar histogram pada berikut. 


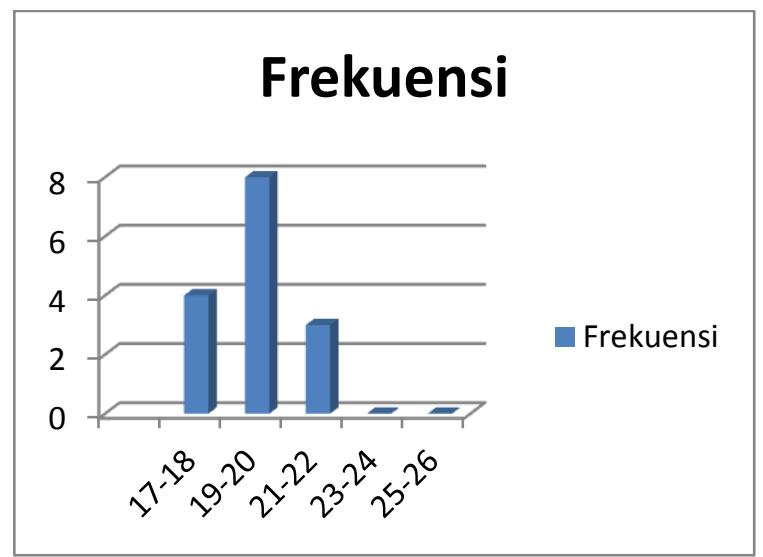

Gambar 5. Histogram Skor Hasil Belajar Ilmu Pengetahuan Sosial Siswa Yang Diajar Dengan Teknik Kunjungan Lapangan Dan Memiliki Gaya Belajar Visual

6. Hasil Belajar Ilmu Pengetahuan Sosial Siswa Yang Diajar Dengan Teknik Kunjungan Lapangan Dan Memiliki Gaya Belajar Auditori

Dari data yang diperoleh dan hasil perhitungan statistik diketahui bahwa hasil belajar Ilmu Pengetahuan Sosial siswa yang diajar dengan teknik kunjungan lapangan dan memiliki gaya belajar auditori, skor terendah 14,skor tertinggi 19 , rata-rata $=16,3$ median $=15,9$ modus $=15,9$ dan simpangan baku =1,49. Distribusi frekuensi skor hasil belajar Ilmu Pengetahuan Sosial siswa yang diajar dengan teknik kunjungan lapangan dan memiliki gaya belajar auditori seperti yang disajikan pada sebagai berikut.
Tabel 7 Distribusi Frekuensi Skor Hasil Belajar Ilmu Pengetahuan Sosial Siswa Yang Diajar Dengan Teknik Kunjungan Lapangan Dan Memiliki Gaya Belajar Auditori

\begin{tabular}{cccc}
\hline No & Interval Kelas & Frekuensi & Persentase (\%) \\
\hline 1 & $14-15$ & 3 & 30 \\
2 & $16-17$ & 5 & 50 \\
3 & $18-19$ & 2 & 20 \\
4 & $20-21$ & 0 & 0 \\
& Jumlah & 10 & 100 \\
\hline
\end{tabular}

Dari Tabel 7 diketahui bahwa hasil belajar Ilmu Pengetahuan Sosial siswa yang diajar dengan teknik kunjungan lapangan dan memiliki gaya belajar auditori, terdapat $70 \%$ di atas rata-rata dan 30\% di bawah rata-rata. Distribusi frekuensi skor hasil belajar Ilmu Pengetahuan Sosial siswa yang diajar dengan teknik kunjungan lapangan dan memiliki gaya belajar auditori secara visual diperlihatkan dalam bentuk gambar histogram pada gambar berikut.

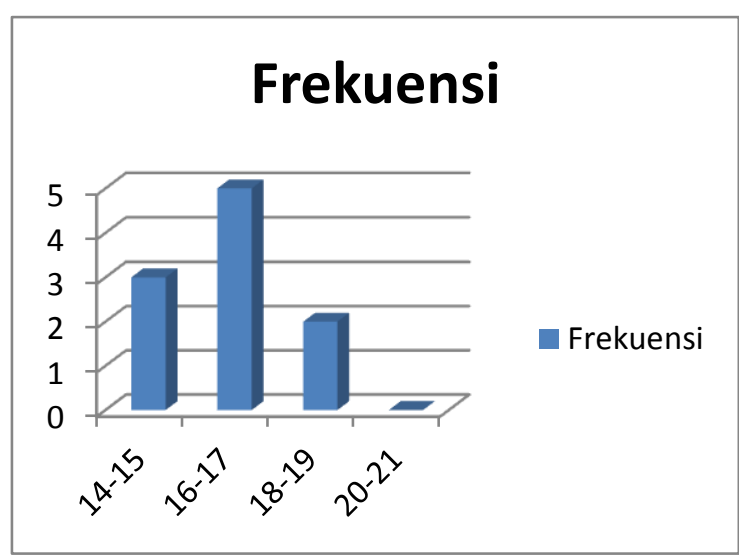

Gambar 6. Histogram Hasil Belajar Ilmu Pengetahuan Sosial Siswa Yang Diajar Dengan Teknik Kunjungan Lapangan Dan Memiliki Gaya Belajar Auditori

7. Hasil Belajar Ilmu Pengetahuan Sosial Yang Diajar Dengan Teknik Penyajian Kasus Dan Memiliki Gaya Belajar Visual 
Dari data yang diperoleh dan hasil perhitungan statistik diketahui bahwa hasil belajar Ilmu Pengetahuan Sosial yang diajar dengan teknik penyajian kasus dan memiliki gaya belajar visual, skor terendah 15 , skor tertinggi 19 , rata-rata $=17,15$, median $=16,75$, modus $=16,9$, simpangan baku $=1,4$. Berdasarkan data tersebut disusun distribusi frekuensi skor hasil belajar Ilmu Pengetahuan Sosial yang diajar denganteknik penyajian kasus dan memiliki gaya belajar visual seperti yang dikemukakan pada berikut.

Tabel 8. Distribusi Frekuensi Skor Hasil Belajar Ilmu Pengetahuan Sosial Yang Diajar Dengan Teknik Penyajian Kasus Dan Memiliki Gaya Belajar Visual.

\begin{tabular}{cccc}
\hline No & Interval Kelas & Frekuensi & $\begin{array}{c}\text { Persentase } \\
(\%)\end{array}$ \\
\hline 1 & $15-16$ & 4 & 31 \\
2 & $17-18$ & 6 & 46 \\
3 & $19-20$ & 3 & 23 \\
& Jumlah & 13 & 100 \\
\hline
\end{tabular}

Dari tabel 8 dapat diketahui bahwa hasil belajar Ilmu Pengetahuan Sosial yang diajar dengan teknik pembelajaran penyajian kasus dan memiliki gaya belajar visual, terdapat $69 \%$ di atas rata-rata dan $31 \%$ di bawah rata-rata. Distribusi frekuensi skor hasil belajar Ilmu Pengetahuan Sosial yang diajar dengan teknik penyajian kasus dan memiliki gaya belajar visual secara visual diperlihatkan dalam bentuk gambar histogram pada berikut.

\section{Frekuensi}

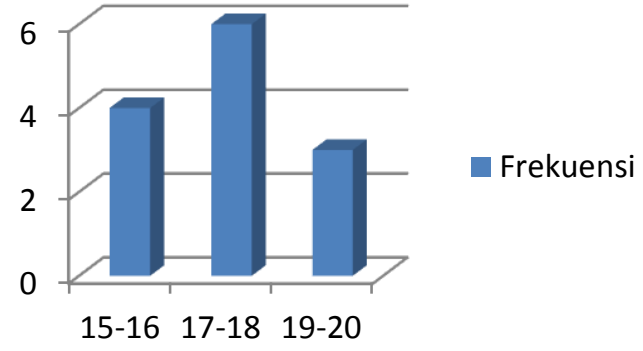

Gambar 7. Histogram hasil belajar Ilmu Pengetahuan Sosial Yang Diajar Dengan Teknik Penyajian Kasus Dan Memiliki Gaya Belajar Visual.

8. Hasil Belajar Ilmu Pengetahuan Sosial Yang Diajar Dengan Teknik Penyajian Kasus Dan Memiliki Gaya Belajar Auditori

Dari data yang diperoleh dan hasil perhitungan statistik diketahui bahwa hasil belajar Ilmu Pengetahuan Sosial yang diajar dengan teknik penyajian kasus dan memiliki gaya belajar auditori, skor terendah 14 ,skor tertinggi 19 , rata-rata $=$ sebesar 16,58, median $=16$, modus $=16$, simpangan baku $=1,44$. Distribusi frekuensi skor hasil belajar Ilmu Pengetahuan Sosial yang diajar dengan teknik penyajian kasus dan memiliki gaya belajar auditori seperti yang disajikan pada tabel berikut.

Tabel 9 Hasil Belajar Ilmu Pengetahuan Sosial Yang Diajar Dengan Teknik Penyajian Kasus Dan Memiliki Gaya Belajar Auditori

\begin{tabular}{cccc}
\hline No & Interval Kelas & Frekuensi & Persentase (\%) \\
\hline 1 & $14-15$ & 3 & 25 \\
2 & $16-17$ & 6 & 50 \\
3 & $18-19$ & 3 & 25 \\
4 & $20-21$ & 0 & 0 \\
& Jumlah & 12 & 100 \\
\hline
\end{tabular}


Dari Tabel 9 diketahui bahwa hasil belajar Ilmu Pengetahuan Sosial yang diajar dengan teknik penyajian kasus dan memiliki gaya belajar auditori memiliki gaya belajar auditori, terdapat $58 \%$ di atas rata-rata, dan $42 \%$ di bawah rata-rata. Distribusi frekuensi skor hasil belajar Ilmu Pengetahuan Sosial yang diajar dengan teknik penyajian kasus dan memiliki gaya belajar auditori, secara visual diperlihatkan dalam bentuk gambar histogram pada gambar berikut.

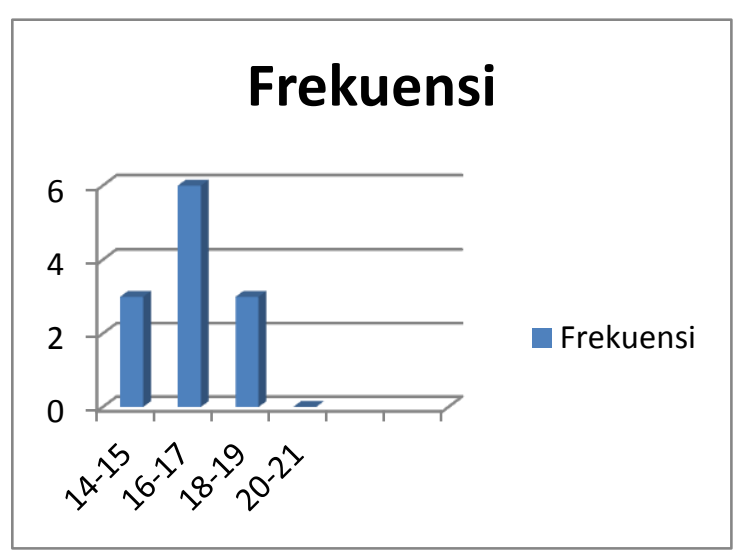

Gambar 8. Histogram Hasil Belajar Ilmu Pengetahuan Sosial Yang Diajar Dengan Teknik Penyajian Kasus Dan Memiliki Gaya Belajar Auditori

Persyaratan pengujian analisis untuk analysis of varians untuk data tiap kelompok telah dipenuhi, yaitu data setiap kelompok berdistribusi normal, memiliki varians yang homogen dan dari sampel yang ditentukan secara random. Dengan demikian uji hipotesis dengan analysis of varians dua jalur dari hasil belajar Ilmu Pengetahuan Sosial dapat dilakukan. Berikut ini akan disajikan pengujian hipotesis penelitian.
Tabel 10. Ringkasan Data Hasil Penelitian Persiapan Perhitungan ANAVA

\begin{tabular}{|c|c|c|c|c|c|}
\hline $\begin{array}{l}\text { Sumber } \\
\text { Variansi }\end{array}$ & Dk & $\mathrm{JK}$ & RK & $\mathrm{F}_{\mathrm{h}}$ & $\begin{array}{c}F_{t} \\
(\alpha=0,05)\end{array}$ \\
\hline $\begin{array}{l}\text { Teknik } \\
\text { Pembelajaran } \\
\text { (A) }\end{array}$ & 1 & 41,3 & 41,3 & 19,86 & 4,05 \\
\hline $\begin{array}{l}\text { Gaya Belajar } \\
\text { (B) }\end{array}$ & 1 & 18 & 18 & 8,65 & 4,05 \\
\hline Interaksi (AB) & 1 & 13,56 & 13,56 & 6,52 & 4,05 \\
\hline Gallat & 46 & 95,65 & 2,08 & - & - \\
\hline Total & 50 & 168,51 & - & - & - \\
\hline
\end{tabular}

Selanjutnya diolah dengan teknik analisis varians faktorial $2 \times 2$, dan diperoleh hasil perhitungan yang disajikan pada tabel berikut. 
Tabel 11. Ringkasan Data Hasil Perhitungan ANAVA Faktorial $2 \times 2$

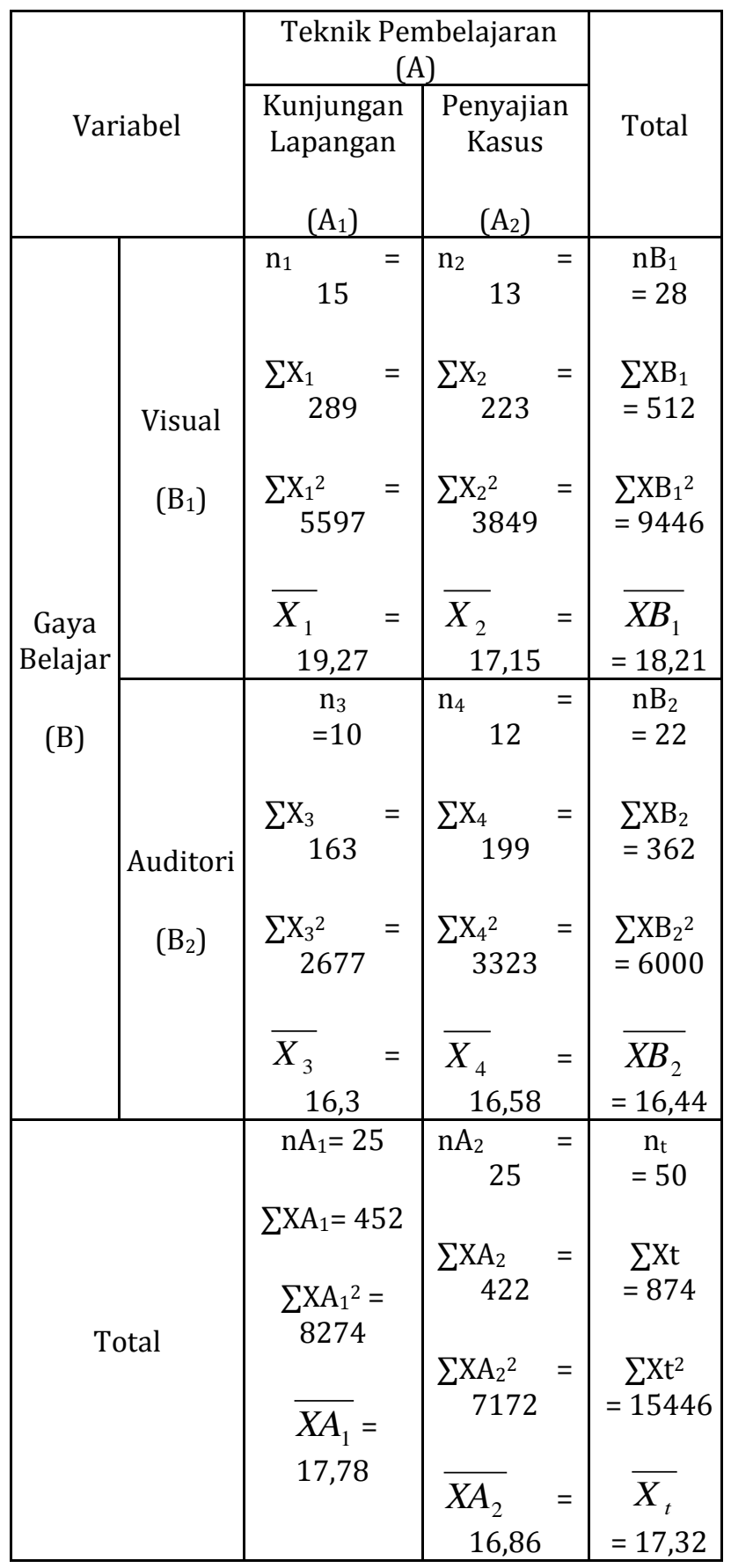

1. Siswa Yang Diajar Dengan Teknik Kunjungan Lapangan Memperoleh Hasil Belajar Ilmu Pengetahuan Sosial Lebih Tinggi Dibandingkan Dengan Siswa Yang Diajar Dengan Teknik Penyajian Kasus
Hipotesis statistik yang diuji adalah :

$$
\begin{aligned}
& \text { Ho: } \mu \mathrm{A}_{1}<\mu \mathrm{A}_{2} \\
& \text { Ha: } \mu \mathrm{A}_{1}>\mu \mathrm{A}_{1}
\end{aligned}
$$

Dari hasil perhitungan diperoleh rata-rata hasil belajar Ilmu Pengetahaun Sosial siswa yang diajar dengan teknik kunjungan lapangan sebesar 17,78 sedangkan hasil belajar Ilmu Pengetahaun Sosial siswa yang diajar dengan teknik penyajian kasus sebesar 16,86. Berdasarkan hasil perhitungan juga diperoleh $F_{\text {hitung }}=19,86$ sedangkan nilai $F_{\text {tabel }}$ pada taraf signifikansi 0,05 sebesar 4,05 dengan demikian $F_{\text {hitung }}>$

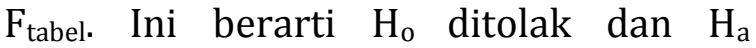
diterima. Dengan demikian dapat dinyatakan bahwa Siswa yang diajar dengan teknik kunjungan lapangan memperoleh hasil belajar Ilmu Pengetahuan Sosial lebih tinggi dibandingkan dengan siswa yang diajar dengan teknik penyajian kasus teruji kebenarannya.

2. Siswa yang Memiliki Gaya Belajar Visual Memperoleh Hasil Belajar Ilmu Pengetahuan Sosial yang Lebih Tinggi Dibandingkan dengan Siswa yang Memiliki Gaya Belajar Auditori

Hipotesis statistik yang diuji adalah:

$$
\begin{aligned}
& \text { Ho: } \mu \mathrm{B}_{1}<\mu \mathrm{B}_{2} \\
& \text { Ha }: \mu \mathrm{B}_{1}>\mu \mathrm{B}_{2}
\end{aligned}
$$

Dari hasil perhitungan diperoleh ratarata hasil belajar Ilmu Pengetahuan Sosial siswa yang memiliki gaya belajar visual sebesar 18,21 sedangkan hasil belajar Ilmu Pengetahuan Sosial siswa yang memiliki gaya belajar auditori sebesar 16,44. Berdasarkan hasil perhitungan juga 
diperoleh $F_{\text {hitung }}=8,65$ sedangkan nilai $F_{\text {tabel }}$ pada taraf signifikansi 0,05 sebesar 4,05 dengan demikian $F_{\text {hitung }}>F_{\text {tabel }}$. Ini berarti $\mathrm{H}_{\mathrm{o}}$ ditolak dan $\mathrm{H}_{\mathrm{a}}$ diterima. Dengan demikian dapat dinyatakan bahwa siswa yang memiliki gaya belajar visual memperoleh hasil belajar Ilmu Pengetahuan Sosial yang lebih tinggi dibandingkan dengan siswa yang memiliki gaya belajar auditori teruji kebenarannya.

3. Terdapat Interaksi antara Teknik Pembelajaran dan Gaya Belajar dalam Mempengaruhi Hasil Belajar Ilmu Pengetahuan Sosial Siswa

Hipotesis statistik yang diuji adalah:

$$
\begin{aligned}
& \text { Ho: } \mathrm{AX} B=0 \\
& \text { Ha: } \mathrm{A} X \mathrm{~B} \neq 0
\end{aligned}
$$

Dari hasil perhitungan diperoleh ratarata hasil belajar Ilmu Pengetahuan Sosial siswa yang diajar dengan teknik kunjungan lapangan sebesar 17,78 sedangkan hasil belajar Ilmu Pengetahuan Sosial siswa yang diajar dengan teknik penyajian kasus sebesar 16,86 dan ratarata rata-rata hasil belajar Ilmu Pengetahuan Sosial siswa yang memiliki gaya belajar visual sebesar 18,21 sedangkan hasil belajar Ilmu Pengetahuan Sosial siswa yang memiliki gaya belajar auditori sebesar16,44.

Berdasarkan hasil perhitungan analisis varians faktorial $2 \times 2$ pada Tabel 11 diperoleh hasil perhitungan data interaksi antara teknik pembelajaran dan gaya belajar terhadap hasil belajar Ilmu Pengetahuan Sosial diperoleh $\mathrm{F}_{\text {hitung }}=6,52$ sedangkan nilai $F_{\text {tabel }}$ pada taraf signifikansi 0,05 sebesar 4,05 dengan demikian $F_{\text {hitung }}>F_{\text {tabel. }}$. Ini berarti $H_{0}$ ditolak dan $\mathrm{H}_{\mathrm{a}}$ diterima. Dengan demikian dapat dinyatakan bahwaterdapat interaksi antara teknik pembelajaran dan gaya belajar dalam mempengaruhi hasil belajar Ilmu Pengetahuan Sosial siswa teruji kebenarannya.

Adapun untuk melihat teknik analisis variansi yang menunjukkan adanya interaksi antara teknik pembelajaran dengan gaya belajar terhadap hasil belajar Ilmu Pengetahuan Sosial dapat disajikan secara visual seperti pada gambar 9 berikut.

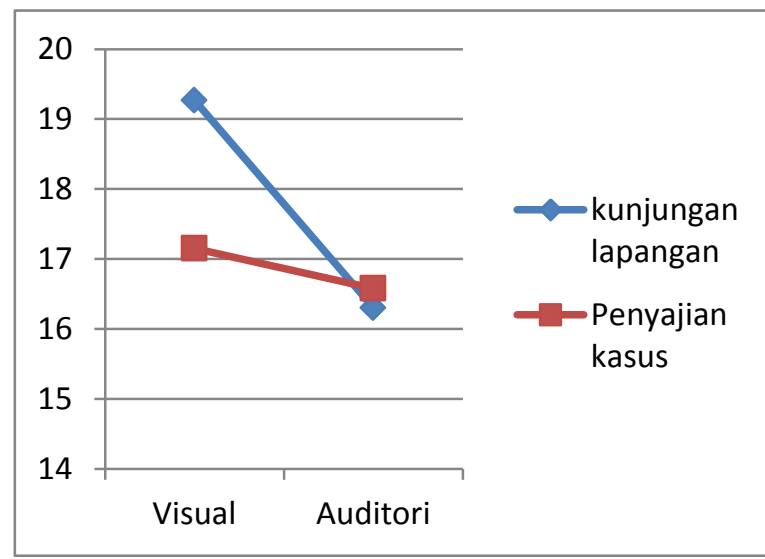

Gambar 9. Interaksi antara Teknik Pembelajaran dengan Gaya Belajar terhadap Hasil Belajar Ilmu Pengetahuan Sosial

Dari Gambar 9 dapat dilihat antara garis pembelajaran dengan teknik kunjungan lapangan membentuk pola interaksi antara teknik pembelajaran dengan gaya belajar. Dari grafik di atas menunjukkan bahwa dalam penelitian ini siswa yang memiliki gaya belajar visual dengan mengikuti teknik kunjungan lapangan lebih tinggi hasil belajarnya dibandingkan dengan siswa yang memiliki gaya belajar auditori dengan mengikuti teknik penyajian kasus. Hal ini mengindikasi adanya interaksi antara teknik pebelajaran dengan gaya belajar. Karena adanya interaksi dan jumlah tiap 
sel tidak sama, maka dilanjutkan dengan melakukan uji Scheffe.

Uji Scheffe untuk mengetahui interaksi antara teknik pembelajaran dengan gaya belajar dalam mempengaruhi hasil belajar Ilmu Pengetahuan Sosial dilakukan uji lanjut dengan menggunakan uji Scheffe. Ringkasan hasil uji Scheffe dapat dilihat pada Tabel 12 berikut
2. Perbandingan kelompok $A_{1} B_{1}$ dengan $\mathrm{A}_{1} \mathrm{~B}_{2}$ diperoleh $\mathrm{F}_{\text {hitung }}>\mathrm{F}_{\text {tabel }}$ sehingga memberikan keputusan menerima Ha. Dengan demikian, hipotesis yang menyatakan bahwa rata-rata hasil belajar Ilmu Pengetahuan Sosial siswa yang diajar dengan teknik kunjungan lapangan dan memiliki gaya belajar visual lebih tinggi dibandingkan ratarata hasil belajar Ilmu Pengetahuan Sosial siswa yang diajar dengan teknik

\begin{tabular}{|c|c|c|c|c|}
\hline No & $\begin{array}{l}\text { Kelompok } \\
\text { Data }\end{array}$ & $\begin{array}{l}\text { Hipotesis } \\
\text { Statistik }\end{array}$ & $\mathrm{F}_{\text {hitung }}$ & $\mathrm{F}_{\text {tabel }}$ \\
\hline 1. & $\begin{array}{l}\text { Kelompok } \\
A_{1} B_{1}: A_{2} B_{1}\end{array}$ & $\begin{array}{l}\mathrm{H}_{0:} \mu_{\mathrm{A} 1 \mathrm{~B} 1}=\mu_{\mathrm{A} 2 \mathrm{~B} 1} \\
\mathrm{Ha}: \mu_{\mathrm{A} 1 \mathrm{~B} 1 \neq} \mu_{\mathrm{A} 2 \mathrm{~B} 1}\end{array}$ & 14,39 & 2,81 \\
\hline 2. & $\begin{array}{l}\text { Kelompok } \\
A_{1} B_{1}: A_{1} B_{2}\end{array}$ & $\begin{array}{l}\mathrm{H}_{0}: \mu_{\mathrm{A} 1 \mathrm{~B} 1}=\mu_{\mathrm{A} 1 \mathrm{~B} 2} \\
\mathrm{H}_{\mathrm{a}}: \mu_{\mathrm{A} 1 \mathrm{~B} 1 \neq} \mu_{\mathrm{A} 1 \mathrm{~B} 2}\end{array}$ & 24,91 & 2,81 \\
\hline 3. & $\begin{array}{l}\text { Kelompok } \\
A_{1} B_{1}: A_{2} B_{2}\end{array}$ & $\begin{array}{l}\mathrm{H}_{0:} \mu_{\mathrm{A} 1 \mathrm{~B} 1}=\mu_{\mathrm{A} 2 \mathrm{~B} 2} \\
\mathrm{H}_{\mathrm{a}}: \mu_{\mathrm{A} 1 \mathrm{~B} 1 \neq} \mu_{\mathrm{A} 2 \mathrm{~B} 2}\end{array}$ & 22,68 & 2,81 \\
\hline 4. & $\begin{array}{l}\text { Kelompok } \\
A_{2} B_{1}: A_{1} B_{2}\end{array}$ & $\begin{array}{l}\mathrm{H}_{0:} \mu_{\mathrm{A} 2 \mathrm{~B} 1}=\mu_{\mathrm{A} 1 \mathrm{~B} 2} \\
\mathrm{H}_{\mathrm{a}}: \mu_{\mathrm{A} 2 \mathrm{~B} 1 \neq} \mu_{\mathrm{A} 1 \mathrm{~B} 2}\end{array}$ & 1,9 & 2,81 \\
\hline 5. & $\begin{array}{l}\text { Kelompok } \\
A_{2} B_{1}: A_{2} B_{2}\end{array}$ & $\begin{array}{l}\mathrm{H}_{0}: \mu_{\mathrm{A} 2 \mathrm{~B} 1}=\mu_{\mathrm{A} 2 \mathrm{~B} 2} \\
\mathrm{H}_{\mathrm{a}}: \mu_{\mathrm{A} 2 \mathrm{~B} 1} \neq \mu_{\mathrm{A} 2 \mathrm{~B} 2}\end{array}$ & 0,958 & 2,81 \\
\hline 6. & $\begin{array}{l}\text { Kelompok } \\
A_{2} B_{2}: A_{1} B_{2}\end{array}$ & $\begin{array}{l}\mathrm{H}_{0}: \mu_{\mathrm{A} 2 \mathrm{~B} 2}=\mu_{\mathrm{A} 1 \mathrm{~B} 2} \\
\mathrm{H}_{\mathrm{a}}: \mu_{\mathrm{A} 2 \mathrm{~B} 2 \neq} \mu_{\mathrm{A} 1 \mathrm{~B} 2}\end{array}$ & 0,21 & 2,81 \\
\hline
\end{tabular}

Berdasarkan Tabel 12, ada 6 pasangan rumusan hipotesis statistik yang diuji menggunakan uji Sceffe, hasil perhitungan pengujian hipotesisnya dijabarkan sebagai berikut :

1. Perbandingan kelompok $A_{1} B_{1}$ dengan $\mathrm{A}_{2} \mathrm{~B}_{1}$ diperoleh $F_{\text {hitung }}>F_{\text {tabel }}$ sehingga memberikan keputusan menerima Ha. Dengan demikian, hipotesis yang menyatakan bahwa rata-rata hasil belajar Ilmu Pengetahuan Sosial siswa yang diajar dengan teknik kunjungan lapangan dan memiliki gaya belajar visual $\left(A_{1} B_{1}\right)$ lebih tinggi dibandingkan rata-rata hasil belajar Ilmu Pengetahuan Sosial siswa yang diajar dengan teknik penyajian kasus dan memiliki gaya belajar visual $\left(A_{2} B_{1}\right)$ teruji kebenarannya.
Kesimkulajungan lapangan memiliki gaya belajar auditori, teruji kebenarannya.

Signifiparapandingan kelompok $\mathrm{A}_{1} \mathrm{~B}_{1}$ dengan

Signifik $2 \mathrm{~B}_{2}$ diperoleh $\mathrm{F}_{\text {hitung }}>\mathrm{F}_{\text {tabel }}$ sehingga Signiffikemberikan keputusan menerima Ha. Dengan demikian, hipotesis yang Tidakenyatakan bahwa rata-rata hasil hasil Signifikan

Tidbelajar Ilmu Pengetahuan Sosial siswa Signifyłæmg diajar dengan teknik kunjungan Tidakpangan memiliki gaya belajar visual lebih tinggi dibandingkan rata-rata hasil belajar Ilmu Pengetahuan Sosial siswa yang diajar dengan teknik penyajian kasus dan memiliki gaya belajar auditori, teruji kebenarannya.

4. Perbandingan kelompok $\mathrm{A}_{2} \mathrm{~B}_{1}$ dengan $A_{1} B_{2}$ diperoleh $F_{\text {hitung }}<F_{\text {tabel }}$ sehingga memberikan keputusan menolak Ha. Dengan demikian, hipotesis yang menyatakan bahwa rata-rata hasil belajar Ilmu Pengetahuan Sosial siswa yang diajar dengan teknik penyajian kasus dan memiliki gaya belajar visual tidak berbeda signifikan dengan hasil belajar Ilmu Pengetahuan Sosial siswa yang diajar dengan teknik pembelajaran kunjungan lapangan memiliki gaya belajar auditori.

5. Perbandingan kelompok $\mathrm{A}_{2} \mathrm{~B}_{2}$ dengan $\mathrm{A}_{2} \mathrm{~B}_{1}$ diperoleh $\mathrm{F}_{\text {hitung }}<\mathrm{F}_{\text {tabel }}$ sehingga memberikan keputusan menolak Ha. 
Dengan demikian, hipotesis yang menyatakan bahwa rata-rata hasil belajar Ilmu Pengetahuan Sosial siswa yang diajar dengan teknik penyajian kasus dan memiliki gaya belajar auditori tidak berbeda signifikan dengan rata-rata hasil belajar Ilmu Pengetahuan Sosial siswa yang diajar dengan teknik penyajian kasus dan memiliki gaya belajar visual.

6. Perbandingan kelompok $A_{2} B_{2}$ dengan $A_{1} B_{2}$ diperoleh $F_{\text {hitung }}<F_{\text {tabel }}$ sehingga memberikan keputusan menolak Ha. Dengan demikian, hipotesis yang menyatakan bahwa rata-rata hasil belajar Ilmu Pengetahuan Sosial siswa yang diajar dengan teknik penyajian kasus dan memiliki gaya belajar auditori tidak berbeda sinifikan dengan hasil belajar Ilmu Pengetahuan Sosial siswa yang diajar dengan teknik kunjungan lapangan memiliki gaya belajar auditori.

\section{SIMPULAN}

Berdasarkan pembahasan yang telah diuraikan di atas, maka dapat ditarik beberapa kesimpulan sebagai berikut Hasil belajar IPS siswa yang diajar dengan Teknik kunjungan lapangan lebih tinggi dibandingkan Hasil belajar IPS siswa yang diajar dengan Teknik penyajian secara kasus. Hasil belajar IPS siswa yang memiliki gaya belajar visual lebih tinggi dibandingkan kelompok siswa yang memiliki gaya belajar auditori. Terdapat interaksi antara teknik pembelajaran dan gaya belajar terhadap hasil belajar IPS siswa. Siswa dengan gaya belajar visual akan memperoleh hasil belajar yang lebih jika diajar dengan teknik kunjungan lapangan. Demikian pula siswa yang memiliki gaya belajar auditori, akan memperoleh hasil belajar yang lebih tinggi jika diajar dengan teknik penyajian kasus.

\section{DAFTAR PUSTAKA}

Arikunto, Suharsimi. 2006. Dasar-dasar Evaluasi Pendidikan. Jakarta : Bumi Aksara.

Cullingford, Cedric. 1995, The Effective Teacher, London: Cassel

De Porter, B \& Hernacki, M. 2002. Quatum Teaching. Bandung: Kaifa

Dick, W dan Carey, L. 1996 the Sistematic Design Of Instruction. Fourth edition, Harper Collins

Dimyati \& Mudjiono, 2006. Belajar dan Pembelajaran. Jakarta: Rineka Cipta.

Djamarah dkk. 20oo. Strategi Belajar Mengajar, Jakarta: Rineka Cipta.

Esler, William K, Mary K Esler. 1996 Teaching Elementary Science, Washington: Wadsworth Publishing Company.

Gulo, Yunita L. 2012. Perbandingan teknik kunjungan lapangan dan teknik penyajian secara kasus terhadap kemampuan menulis berita siswa kelas $\mathrm{x}$ sma negeri 4 padangsidimpuan. Unimed

Gunawan, Adi W. 2006. Genius Learning Strategi. Jakarta: Pustaka Utama.

Gunawan, Rudy. 2011. Pendidikan IPS Filosofi, Konsep dan Aplikasi. Bandung: Alfabeta.

Hidayati dkk. 20o8. Pengembangan Pendidikan IPS SD. Jakarta: Direktorat Jendral Pendidikan Tinggi Departemen Pendidikan Nasional.

Iriani, Dewi. 2013. Identifikasi Gaya Belajar dan Pengaruhnya terhadap Hasi Belajar Siswa pada Materi Kubus dan Balok di Kelas VIII SMPN 2 Kerinci, (online), Vol 1, No 1.Universitas Lampung. Diakses pada 11 ei 2014

Izzaty, Rita Eka dkk. 2008. Perkembangan Peserta Didik. Yogyakarta: UNY Press.

Khosiyah , 2012, Pengaruh Strategi Pembelajaran dan Gaya Belajar Terhadap Hasil Belajar Pendidikan Agama Islam Siswa SD INTI no. o6o873 MEDAN , (Online) Vol. 9 No.1, Jurnal Tabularasa PPS UNIMED

Roestyah. 2012. Strategi Belajar Mengajar. Jakarta : PT Asdi Mahasatya.

Rose, Colin dan Malcolm J. Nicholl. 2002. Accelerated Learning. Bandung: Nuansa.

Ritonga, Dewi Safitri. 2013. Kemampuan menulis paragraf deskripsi siswa kelas x sma swasta prayatna medan tahun ajaran 2012/2013, 
(Online), vol 2 No 3. Universitas Negeri Medan. Diakses pada 11 januari 2014

Simare mare, Marulian. 2011. Pengaruh Pemberian Tugas dan Gaya Belajar Terhadap Hasil Belajar PPKN Kelas V SD. Negeri No.117840 Selat Cina Desa Selar Besar Kecamatan Bilah Hulu Kabupaten Labuhan Batu, Medan: Pasca Unimed

Slameto, 2003. Belajar dan Faktor-Faktor Yang Mempengaruhinya. Jakarta : Rineka Cipta.

Sudjana. 2005. Metode Statitiska. Bandung: Tarsito

Sudjana. 2008. Metode dan teknik Pembelajaran Partisipatif. Bandung : Falah Production.

Sriyono, 1992. Teknik Belajar Mengajar dalam CBSA, Jakarta: Rineka Cipta.

Syah, Muhibbin. (2008). Orientasi Baru dalam Psikologi Pembelajaran, Jakarta: Bumi Aksara

Taneo, Silvester Petrus, dkk. 2009. Kajian IPS SD. Jakarta: Dikti, Depdiknas.

Wulandari, Wina.2011. Pengaruh teknik field visit terhadap kemampuan Menulis berita oleh siswa kelas viii Smp swasta budi agung medan marelan Tahun pembelajaran 2010/2011, (Online), Vol 1, No 1 Universitas Negeri Medan. Diakses pada 20 desember 2013.

Admin. 2008. Beda Strategi, Model, Pendekatan, Metode, dan Teknik Pembelajaran. (http://smacepiring.wordpress.com/).

Diakses pada 8 Mei 2014

Al-hafidh, Ridha. 2012. Pengertian Teknik Dalam Pembelajaran.

http://www.referensimakalah.com/2012/o9 /pengertian-teknik-dalampembelajaran.html. Diakses 10 mei 2014

Ayyash. 2011. http://guide prof.blogspot.com/2011/o9/metodemedote-pembelajaran.html. Diakses 10 mei 2014

Delnitawati, Sujarwo. 2013. Pengaruh Metode Pembelajaran Dan Gaya Belajar Terhadap Hasil Belajar. http://www.umnaw.ac.id/wpcontent/uploads/2013/o1/Laporan-

Sujarwo.pdf. Diakses 1o Agustus 2014

Gobai, Yosep. 2005. "Pengaruh Penggunaan Bahan Ajar Dan Gaya Belajar Terhadap Hasil Belajar". http://researchengines.com/arto5- 94.html. Diakses 30 maret 2014

Sudrajat, Ahmad. 2008. Pengertian Pendekatan, Strategi, Metode, Teknik, Taktik danModel Pembelajaran.http://akhmadsud rajat.wordpress.com/2008/o9/12/pendekata n-strategi-metode-teknik-dan-modelpembelajaran/. Diakses 10 mei 2014 